\title{
Assessing organic potato cropping systems at the end of the first cycle of four-year rotations using principal component analysis
}

\author{
K. Liu', A. M. Hammermeister ${ }^{1}$, D. G. Patriquin ${ }^{2}$, and R. C. Martin ${ }^{1}$ \\ ${ }^{1}$ Organic Agriculture Centre of Canada, Nova Scotia Agricultural College, Box 550, Truro, Nova Scotia, Canada \\ B2N 5E3; and ${ }^{2}$ Department of Biology, Dalhousie University, Halifax, Nova Scotia, Canada B3H 4 J1. \\ Received 3 March 2007, accepted 5 February 2008.
}

Liu, K., Hammermeister, A. M., Patriquin, D. G. and Martin, R. C. 2008. Assessing organic potato cropping systems at the end of the first cycle of four-year rotations using principal component analysis. Can. J. Soil Sci. 88: 543-552. A single or a few variables may not be sufficient to evaluate management practice effects in a complicated cropping system, so six plant and 13 soil variables were integrated using principal component analysis (PCA) to examine nine 4-yr organic potato rotations. The rotations were combinations of three forage levels $(0,1$, and $2 \mathrm{yr}$ of forages) with three soil amendments (monogastric compost, ruminant compost, and alfalfa meal). Quantities of amendments were estimated by soil test recommendations and amendment nutrient availabilities. In the 4th potato year, one half of each original plot was not amended ("the 4th year unamended plots"), while the other half received soil amendments ("4th year amended plots"). The first three principal components explained 67 and $63 \%$ of the overall variation for the $4^{\text {th }}$-yr amended and unamended plots, respectively. PCA ordination plots indicated that, overall, the type of soil amendments had larger effects on soil and plant variables, but forage frequencies were influential for the amendments showing weaker effects. PCA loading plots indicated that plant nutrient uptake and potato total tuber weight would be the best single variables for characterizing the current cropping systems. Plant variables, except for potato petiole nitrate, were closely displayed, but they were not strongly correlated with soil variables, which may reflect the high background fertility of this site. Applications of soil amendments in the 4th yr affected the relationships among variables, most notably the strength of relationships between soil $\mathrm{pH}$ and soil $\mathrm{N}$ variables. The results suggest that PCA provides an effective way to compare complex cropping systems, especially in situations with high site heterogeneity.

Key words: Principal component analysis, soil amendment, livestock system, forage, potato, organic crop rotation

Liu, K., Hammermeister, A. M., Patriquin, D. G. et Martin, R. C. 2008. Évaluation de systèmes de culture biologique de la pomme de terre à la fin du premier cycle d'un assolement de quatre ans par l'analyse en composantes principales. Can. J. Soil Sci. 88: 543-552. L'analyse d'une ou de quelques variables pourrait ne pas suffire quand on souhaite évaluer l'incidence des pratiques culturales dans un système agricole complexe. C'est pourquoi les auteurs ont intégré 6 variables végétales et 13 variables du sol à l'analyse en composantes principales (ACP) dans l'étude d'un assolement de quatre ans avec culture biologique de la pomme de terre. Les assolements consistaient en trois cultures fourragères $(0,1$ et 2 années de culture) et trois amendements (compost de monogastrique, compost de ruminant et luzerne en poudre). La quantité d'amendement a été estimée après analyse du sol, en fonction de la concentration d'éléments nutritifs disponible. La moitié de chaque parcelle originale n'a pas été bonifiée la quatrième année, soit l'année où l'on a cultivé la pomme de terre (parcelles non amendées la $4^{\mathrm{e}}$ année), tandis que l'autre moitié l'a été (parcelles amendées la $4^{\mathrm{e}}$ année). Les trois premières composantes principales expliquent respectivement $67 \%$ et $63 \%$ de la variation globale pour les parcelles amendées et celles non amendées la $4^{\mathrm{e}}$ année. Ordonnées en fonction des résultats de l'ACP, les parcelles indiquent que le type d'amendement a généralement plus d'effets sur les variables des plantes et du sol, mais la fréquence des cultures fourragères joue un rôle quand les amendements ont une plus faible incidence. Les courbes obtenues avec l'ACP révèlent que l'assimilation des éléments nutritifs par les plantes et le poids total des tubercules constituent les meilleures variables simples permettant de caractériser les systèmes agricoles existants. Hormis la concentration de nitrate dans le pétiole de la pomme de terre, les variables végétales sont voisines des variables du sol, mais elles ne sont pas fortement corrélées avec elles, ce qui pourrait

\begin{abstract}
Abbreviations: $\mathbf{C}_{\text {tot }}$, total C; DHA, dehydrogenase enzyme activity; M, monogastric livestock systems where composted monogastric manure was used as the main nutrient source; $\mathbf{N}_{\text {tot }}$, total $\mathbf{N} ;$ PCA, principal component analysis; $\mathbf{R}$, ruminant livestock systems where composted ruminant manure was used as the main nutrient source; $\mathbf{S}$, stockless systems where alfalfa meal was used as the main $\mathrm{N}$ source and rock $\mathrm{P}$ was used as the main phosphorus source; SMBC, soil microbial biomass carbon
\end{abstract}


s'expliquer par la grande fertilité naturelle du site. L'amendement du sol la $4^{\mathrm{e}}$ année altère les liens entre les variables, particulièrement entre le $\mathrm{pH}$ du sol et les variables liées à l'azote. Ces résultats laissent croire que l'ACP est une bonne façon de comparer des systèmes agricoles complexes, surtout lorsque les sites sont très hétérogènes.

Mots clés: Analyse en composantes principales, amendement du sol, élevage, fourrage, pomme de terre, assolement biologique

Forages and composted livestock manures are widely used as nitrogen $(\mathrm{N})$ sources in organic systems, and also influence supply of other nutrients and soil physical properties. Quantities of soil amendments needed to achieve a desired $\mathrm{N}$ supply in a given year are usually expected to be affected by forage frequency in a given rotation; they are also affected by the type of soil amendments and the availability of the contained $\mathrm{N}$. Potatoes are an important crop in the Canadian Maritimes. Growing potatoes organically requires large inputs of $\mathrm{N}$ through nitrogen fixation in forages and the use of soil supplements. As well, forages and manures are now widely used in conventional production to reverse soil degradation associated with monocropping of potatoes (Angers et al. 1999; Carter et al. 2003; Stark and Porter 2005).

A wide range of cropping systems is possible with different types and levels of forages and soil amendments, and many soil and plant variables may be required to characterize the different systems. Analysis and interpretation of the large data sets can be complex, and considerable information about the systems may be lost if conclusions are based primarily on statistical significance tests. In a soil fertility study, individual variables showed divergent trends over a 6-yr crop rotation, making it difficult to draw a solid conclusion about changes in soil fertility (Bakken et al. 2006). Alternatively, system evaluation can be enhanced by using integrative indicators (Gil-Sotres et al. 2005). The method of principal component analysis (PCA) is increasingly used to summarize large data sets in agricultural studies (Marinari et al. 2006). Compared with univariate methods, PCA, along with cluster analysis, can provide a better understanding of system performance and lead to a more convincing interpretation of management practices (Sena et al. 2002). PCA can also be used to suggest which individual variables or smaller set of variables might be most informative for routine monitoring (Andrews and Carroll 2001).

The objectives of the current study were: (1) compare nine different organically managed potato cropping systems using 19 soil and plant variables by PCA ordination plots; and (2) examine the relationships among the 19 soil and plant variables by using PCA loading plots.

\section{MATERIALS AND METHODS}

\section{Experimental Design}

The experiment was established on a long-term pasture in Truro (lat. $45^{\circ} 14^{\prime} \mathrm{N}$, long. $63^{\circ} 19^{\prime} \mathrm{W}$ ), Nova Scotia, Canada, in the spring of 2002 . The loam soil ( $40 \%$ sand,
$38 \%$ silt, and $22 \%$ clay) is classified as an Orthic Humoferric Podzol. This experiment was arranged as a two-stage nested design, with the soil amendment factor nested under the forage factor. This experiment is a nested design, since the application rates of three amendments were similar, but not identical among the three forage levels, depending on the rotations and their cumulative effects on soil fertility as described below. The nine forage and soil amendment combinations were completely randomized within a block, with three blocks separated by a $3-\mathrm{m}$ alley. Each plot was $3 \mathrm{~m}$ wide and $10 \mathrm{~m}$ long with a $1-\mathrm{m}$ tilled buffer between plots. The nine different organic cropping systems were represented by the combinations of forages and soil amendments. The forage factor had three forage treatments represented by three 4-yr crop rotations. Each rotation started with wheat (Triticum aestivum L.) in year 1 and ended with potato (Solanum tuberosum L.) in year 4. Crops in years 2 and 3 were soybean (Glycine max L.)barley (Hordeum vulgare L.) for the 0 -yr forage treatment, barley-forage [a mixture of red clovers (Trifolium pratense L.) and timothy (Phleum pretense L.)] for the $1-\mathrm{yr}$ forage treatment, and forage-forage for the 2-yr forage treatment. Forages were underseeded into wheat or barley in the year prior to the forage crop year. The three soil amendments represented the main nutrient sources of three farming systems: (1) a stockless system without livestock (S): alfalfa meal was the primary $\mathrm{N}$ source for wheat, barley and potatoes, $\mathrm{P}$ was supplemented with rock $\mathrm{P}$ (calcium phosphate) as required beyond that applied with alfalfa meal; rock $\mathrm{P}$ was the primary $\mathrm{P}$ source for soybean and forage crops; forages, if applicable, were used as mulch in potato crops and cereal straw was retained in the plots; (2) a monogastric system (M) and (3) a ruminant system (R), where composted manure (monogastric or ruminant as appropriate) was the primary $\mathrm{N}$ source for wheat, barley and potatoes, and the $\mathrm{P}$ source for forage crops; $\mathrm{P}$ was supplemented with rock $\mathrm{P}$ as required; forages were removed for feed where applicable; cereal straw was removed for bedding.

\section{Soil Fertility and Crop Management}

We assumed that $30 \%$ of $\mathrm{N}_{\text {tot }}$ in alfalfa meal, $50 \%$ of $\mathrm{N}_{\text {tot }}$ in composted monogastric manure, and $25 \%$ of $\mathrm{N}_{\text {tot }}$ in composted ruminant manure were plant available based on experiments conducted in the local area (Warman and Cooper 2000; Rodd et al. 2002; Mkhabela and Warman 2005). We further assumed that $20 \%$ of $\mathrm{P}_{\text {tot }}$ in alfalfa meal, composted monogastric manure, and composted ruminant manure was plant available in 


\begin{tabular}{|c|c|c|c|c|c|c|c|c|c|}
\hline \multirow[b]{2}{*}{ Factor } & \multicolumn{3}{|c|}{ Year 1} & \multicolumn{3}{|c|}{ Year 3} & \multicolumn{3}{|c|}{ Year 4} \\
\hline & DW & $\mathrm{C}_{\mathrm{tot}}$ & $\begin{array}{c}\mathrm{N}_{\text {tot }} \\
\left(\mathrm{kg} \mathrm{ha}^{-1}\right)\end{array}$ & DW & $\begin{array}{l}\mathrm{C}_{\mathrm{tot}} \\
-1)\end{array}$ & $\begin{array}{c}\mathrm{N}_{\text {tot }} \\
\left(\mathrm{kg} \mathrm{ha}^{-1}\right)\end{array}$ & DW & $\begin{array}{l}\mathrm{C}_{\mathrm{tot}} \\
\left.{ }^{1}\right)\end{array}$ & $\begin{array}{c}\mathrm{N}_{\text {tot }} \\
\left(\mathrm{kg} \mathrm{ha}^{-1}\right)\end{array}$ \\
\hline \multicolumn{10}{|c|}{ Forage level $^{\mathrm{y}}$} \\
\hline 0 & 24.4 & 8.4 & 529 & 12.7 & 2.6 & 196 & 14.2 & 2.7 & 206 \\
\hline 1 & 24.4 & 8.4 & 529 & 26.4 & 3.9 & 304 & 13.2 & 2.5 & 189 \\
\hline 2 & 12.2 & 4.2 & 264 & 23.5 & 3.2 & 252 & 12.2 & 2.6 & 190 \\
\hline \multicolumn{10}{|c|}{ Forage $\times$ Soil amendment ${ }^{\mathrm{x}}$} \\
\hline M0 & 20.9 & 4.3 & 340 & 18.3 & 1.5 & 125 & 24.2 & 1.9 & 172 \\
\hline R0 & 25.9 & 8.9 & 680 & 14.1 & 3.9 & 296 & 10.1 & 2.6 & 252 \\
\hline S0 & 26.5 & 12.1 & 567 & 5.6 & 2.5 & 166 & 8.4 & 3.7 & 193 \\
\hline M1 & 20.9 & 4.3 & 340 & 40.9 & 3.3 & 278 & 22.6 & 1.8 & 161 \\
\hline R1 & 25.9 & 8.9 & 680 & 38.2 & 8.3 & 633 & 10.0 & 2.6 & 250 \\
\hline $\mathrm{S} 1$ & 26.5 & 12.1 & 567 & 0 & 0 & 0 & 6.9 & 3.0 & 158 \\
\hline M2 & 10.4 & 2.1 & 170 & 42.4 & 3.4 & 288 & 18.4 & 1.4 & 131 \\
\hline R2 & 12.9 & 4.4 & 340 & 28.2 & 6.1 & 468 & 9.4 & 2.4 & 236 \\
\hline S2 & 13.2 & 6.1 & 283 & 0 & 0 & 0 & 8.9 & 3.9 & 204 \\
\hline
\end{tabular}

${ }^{\mathrm{z}}$ Abbreviations: $\mathrm{C}_{\text {tot }}$, total carbon; DW, dry matter; $\mathrm{N}_{\text {tot }}$, total $\mathrm{N} ; \mathrm{M}$, monogastric livestock systems where composted monogastric manure was used as the main nutrient source; $\mathrm{R}$, ruminant livestock systems where composted ruminant manure was used as the main nutrient source; $\mathrm{S}$, stockless systems where alfalfa meal was used as the main $\mathrm{N}$ source and rock-P was used as the main phosphorus source.

${ }^{y_{0}} 0$ : 0 -yr forage level represented by the rotation of wheat-soybean-barley-potato; 1, 1-yr forage level represented by the rotation of wheat-barleyforage-potato; 2, 2-yr forage level represented by the rotation of wheat-forage-forage-potato.

${ }^{\mathrm{x}} \mathrm{M} 0, \mathrm{M} 1$, and $\mathrm{M} 2$ represent 0-, 1-, and 2-yr forages in 4-yr crop rotations amended with composted monogastric manures, respectively; R0, R1, and $\mathrm{R} 2$ represent 0-, 1-, and 2-yr forages in 4-yr crop rotations amended with composted ruminant manures, respectively; and S0, S1, and S2 represent 0-, $1-$, and 2-yr forages in 4-yr crop rotations amended with alfalfa meal, respectively.

the application year. Amendment application rates were managed to simulate practices on mixed (livestock + crops) and stockless (crops only) organic farms, where the goal is to grow crops without significant nutrient limitations and at the same time to avoid excessive nutrient inputs. Soil amendment application rates varied according to crops, soil test recommendations provided by a government laboratory, analysis of the amendments, and assumptions of nutrient availability from each amendment. Soil amendment application rates in the whole crop rotations are listed by year in Table 1 . In year 1, amendment application rates for $\mathrm{N}$ were reduced by $50 \%$ in the 2 -yr forage rotations where wheat plots were underseeded with forage crops, in order to let red clover biologically fix atmospheric $\mathrm{N}_{2}$ rather than take up soil N. No amendments were applied in year 2 according to the soil test recommendations. In year 3, amendment application rates were recommended based on crop $\mathrm{N}$ requirements except in the forage plots where application rates were recommended according to forage $\mathrm{P}$ requirements. In the 4 th $\mathrm{yr}$ of potatoes, each original plot was split into two subplots. A randomly selected one-half of each plot was amended and denoted as a 4th yr amended plot, while the other half was left unamended and denoted as a 4 th yr unamended plot. In the 4th yr amended plots, amendments were applied to bring available $\mathrm{N}$ up to levels recommended for potatoes, making allowances for anticipated inputs of $\mathrm{N}$ from legume forages.

Wheat, barley, and soybean were seeded with an eight row (1.25-m-wide) Hege 80 cereal seeder, and forages were seeded with a Brillion SS12 forage seeder. Wheat, barley, and soybean were harvested with a Hege 1250C plot combine. Forages were cut twice per year at the $10 \%$ bloom stage with a Haldrup 1500 forage harvester. To prepare for the potato year, all plots were moldboard ploughed to a depth of $20 \mathrm{~cm}$ in the late fall of year 3 . In the spring of year 4 , the potato seed bed was prepared by one pass of disc harrowing followed by two passes of a light cultivator (5220 Odense, Denmark). Soon after potato hilling, potatoes in 1- and 2-yr forage rotations in the $\mathrm{S}$ treatments were mulched with forages produced from separately managed plots in accordance with the stockless system. Mulch rates were equivalent to the first cut forage biomass from a single plot size of $3 \times 10 \mathrm{~m}$ in the 1-yr forage rotations and double plot size in the 2-yr forage rotations. Colorado potato beetles (Leptinotarsa decemlineata) were controlled by spraying Entrust ${ }^{\circledR}$ (organically permitted) three times after potato flowering at a rate of $0.1 \mathrm{~L} \mathrm{ha}^{-1}$. To prevent potato late blight (Phytophthora infestans), copper hydroxide was sprayed three times after onset of flowering at a rate of $3 \mathrm{~L} \mathrm{ha}^{-1}$. Potatoes were harvested using a Niplo D-653S single row potato digger.

\section{Soil and Plant Sampling and Laboratory Analyses} Potato biomass was collected in both the 4th $\mathrm{yr}$ amended and unamended potato plots. Oven dried plant samples were ground through a Retch centrifuge mill with a $1-\mathrm{mm}$ stainless steel sieve for total nutrient analysis. Plant $\mathrm{C}$ and $\mathrm{N}$ were determined by combustion at $950^{\circ} \mathrm{C}$ with an automatic Leco ${ }^{\circledR}$ analyzer (CNS-1000, 
LECO Corporation, St-Joseph, MI). Plant P and K contents were determined by nitric acid digestion method as described by Zheljazkov and Warman (2002). Potato petioles were collected at the potato flowering stage, and potato petiole nitrate was extracted with deionized water (Schulte et al. 1987), and the filtered extract was analyzed by flow injection analyzer (Lachat Quickchem 8000).

Fifteen soil cores in both the 4th yr amended and unamended potato plots to a depth of $15 \mathrm{~cm}$ were randomly collected soon after potato harvesting, and one composite sample per plot was formed. Composite soil samples were immediately screened through a 1-mm sieve for determining soil available $\mathrm{N}$ (Maynard and Kalra 1993), SMBC (Voroney et al. 1993), and DHA (von Mersi and Schinner 1991). Soil C and N were determined using a Leco ${ }^{\circledR}$ analyzer. Soil extractable P and $\mathrm{K}$ were determined using Mehlich 3 extraction (Mehlich 1984) followed by analysis using a Jarrell-Ash ICAP 9000 (Waltham, MA) spectrometer. Soil N supply rates were measured at the potato flowering stage using ion exchange membranes as plant root simulator $\left(\mathrm{PRS}^{\mathrm{TM}}\right.$ ) probes (Western Ag. Innovations, Inc., Saskatoon, SK).

\section{Statistical Analysis}

Principal component analysis was conducted on soil and plant data by PROC PRINCOMP with SAS (SAS Institute, Inc. 1999). Ordination and loading plots were commonly presented in PCA. An ordination plot is a map reflecting similarities and differences among treatments after reduction of a multivariate data set (Clarke and Warwick 2001). Smaller distances between treatments can be interpreted as representing increased similarity between treatments compared with treatments separately by larger distances. In a loading plot, the vectors pointing in approximately the same direction can be interpreted as representing positive correlations between variables represented by the vectors. The length of the vectors is proportional to the importance of the variables presented by the vectors in explaining how well the single variable may substitute for a given principal component (James and McCulloch 1990). Prior to the PCA, normal distribution for each variable was individually verified by examining the residuals according to the experimental design (i.e., nested design for this experiment). Soil extractable $\mathrm{K}$ in the 4 th $\mathrm{yr}$ unamended plots was reciprocal transferred, and a $\log$ transformation was performed for potato biomass $\mathrm{C}$ and potato $\mathrm{P}$ uptake to meet the normal distribution of the error term assumption. To test and display the similarities and differences among treatments, the first three principal components were subjected to cluster analysis by PROC TREE with the average method in SAS (SAS Institute, Inc. 1999). Variable comparisons between the 4th yr amended and unamended plots were conducted using paired t-tests with Minitab (Minitab Inc. 2004). Regression analysis between $\mathrm{pH}$ and soil extractable $\mathrm{N}$ was conducted using Proc Reg of SAS (SAS Institute, Inc. 1999). The data in the 4th yr amended and unamended plots were analyzed separately.

\section{RESULTS AND DISCUSSION}

\section{Comparison of Cropping Systems}

The differences in average values of plant and soil variables were relatively small between the 4th yr amended and unamended plots (Table 2), as were average values for different amendments and for different forage levels (Liu 2006). The values of many of the variables, however, varied by two- to three-fold or higher among plots (Table 2). Small scale heterogeneity of this sort is probably typical, even of seemingly uniform cultivated fields (Robertson et al. 1997). The

\begin{tabular}{|c|c|c|c|}
\hline Variables (unit) & 4th yr amended plots & 4th yr unamended plots & $P$ values \\
\hline Soil bulk density (SBD) $\left(\mathrm{g} \mathrm{cm}^{-3}\right)$ & $0.98(0.83-1.11)$ & $0.99(0.88-1.09)$ & 0.202 \\
\hline Soil moisture (SM) $(\%)$ & $19(16-23)$ & $18(10-22)$ & 0.190 \\
\hline Soil pH & $6.1(5.5-6.6)$ & $6.1(5.5-6.6)$ & 0.958 \\
\hline Cation exchange capacity $(\mathrm{CEC})\left(\mathrm{cml}_{\mathrm{c}} \mathrm{kg}^{-1}\right)$ & $15(13-19)$ & $15(14-19)$ & 0.264 \\
\hline Soil total carbon $\left(\mathrm{SC}_{\mathrm{tot}}\right)\left(\mathrm{g} \mathrm{kg}^{-1}\right)$ & $31.6(26.0-36.2)$ & $30.4(27.5-36.0)$ & 0.019 \\
\hline Soil total nitrogen $\left(\mathrm{SN}_{\mathrm{tot}}\right)\left(\mathrm{g} \mathrm{kg}^{-1}\right)$ & $2.4(2.2-2.8)$ & $2.2(2.1-2.6)$ & 0.009 \\
\hline Soil extractable nitrogen $(\mathrm{SN})\left(\mathrm{g} \mathrm{kg}^{-1}\right)$ & $0.030(0.024-0.048)$ & $0.028(0.024-0.046)$ & 0.218 \\
\hline Soil N supply rates (SNSR) $\left(\mu \mathrm{g} 10 \mathrm{~cm}^{-2} 2 \mathrm{wk}^{-1}\right)$ & $814(715-1194)$ & $759(398-1019)$ & 0.107 \\
\hline Soil extractable phosphorus (SP) $\left(\mathrm{g} \mathrm{kg}^{-1}\right)$ & $0.208(0.08-0.405)$ & $0.159(0.08-0.256)$ & 0.004 \\
\hline Soil extractable potassium (SK) $\left(\mathrm{g} \mathrm{kg}^{-1}\right)$ & $0.27(0.14-0.45)$ & $0.22(0.13-0.33)$ & 0.001 \\
\hline Soil soluble carbon (SC) $\left(\mathrm{mg} \mathrm{kg}^{-1}\right)$ & $173(106-234)$ & $174(146-246)$ & 0.918 \\
\hline Soil microbial biomass $\mathrm{C}$ (SMBC) $\left(\mathrm{mg} \mathrm{kg}^{-1}\right)$ & $961(638-1413)$ & $881(534-1307)$ & 0.180 \\
\hline Dehydrogenase activity(DHA) (nmol INTF $\mathrm{g}^{-1} \mathrm{~h}^{-1}$ ) & $135(74-205)$ & $133(79-238)$ & 0.841 \\
\hline Potato petiole nitrate (Pnitrate) $(\%)$ & $0.91(0.59-1.32)$ & $0.90(0.64-1.27)$ & 0.620 \\
\hline Plant carbon biomass (PC) $\left(\mathrm{kg} \mathrm{ha}^{-1}\right)$ & $2925(1152-4948)$ & $2471(1151-4850)$ & 0.003 \\
\hline Plant nitrogen uptake $(\mathrm{PN})\left(\mathrm{kg} \mathrm{ha}^{-1}\right)$ & $114(62-169)$ & $103(26-205)$ & 0.017 \\
\hline Plant phosphorus uptake (PP) $\left(\mathrm{kg} \mathrm{ha}^{-1}\right)$ & $14(11-22)$ & $13(7-26)$ & 0.190 \\
\hline Plant potassium uptake (PK) $\left(\mathrm{kg} \mathrm{ha}^{-1}\right)$ & $186(78-337)$ & $142(36-353)$ & 0.001 \\
\hline Dry potato tuber yield (PTW) $\left(\mathrm{kg} \mathrm{ha}^{-1}\right)$ & $5706(2844-8916)$ & $4963(2437-8689)$ & 0.039 \\
\hline
\end{tabular}


first three principal components in the PCA ordination explained $67 \%$ of the overall variation of plant and soil variables for the 4th yr amended plots (Fig. 1a) and 63\% of that for the 4th yr unamended plots (Fig. 1b). The fourth principal component explained an additional $8 \%$ in both the 4th $\mathrm{yr}$ amended and unamended plots. The PCA three-dimensional ordination and cluster analysis for the 4th yr amended plots illustrates clustering of the alfalfa meal treatments (i.e., those of the simulated
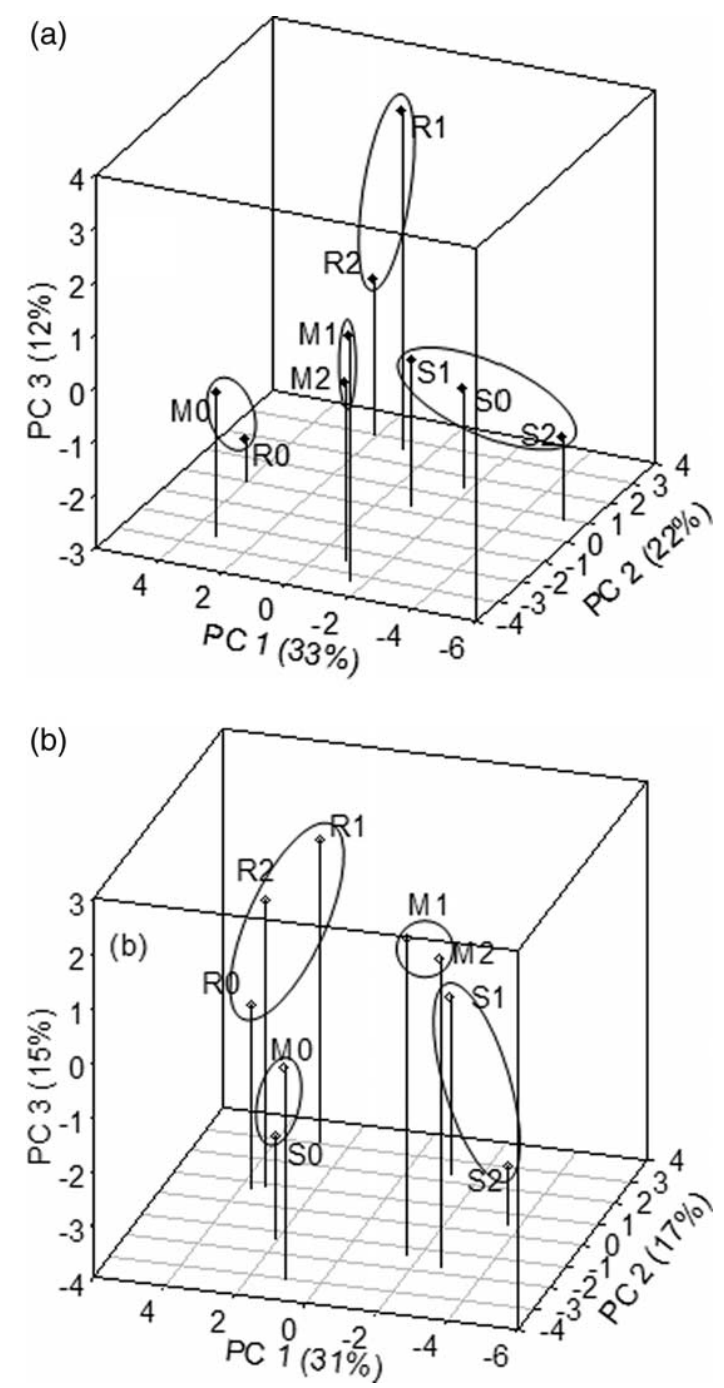

Fig. 1. Three-dimension ordination of the first three principal components (a) the 4th yr amended plots and (b) the 4th yr unamended plots. Groupings were determined by cluster analysis. M0, M1, and M2 represent 0-, 1-, and 2-yr forages in 4-yr crop rotations amended with composted monogastric manures, respectively; R0, R1, and R2 represent 0-, 1-, and 2 -yr forages in 4-yr crop rotations amended with composted ruminant manures, respectively; and $\mathrm{S} 0, \mathrm{~S} 1$, and $\mathrm{S} 2$ represent $0-, 1-$, and 2-yr forages in 4-yr crop rotations amended with alfalfa meal, respectively. stockless system), which were clearly separated from compost treatments (i.e., those of the simulated mixed system). The separation of the alfalfa meal treatments from compost treatments may be attributable to higher soil available $\mathrm{N}$ levels in alfalfa meal treatments than in compost treatments, since alfalfa meal has higher readily decomposable $\mathrm{C}$ and $\mathrm{N}$, which stimulate soil microbial activity and lead to high available $\mathrm{N}$ compared with composts (Liu 2006). In the ordination for the 4th $\mathrm{yr}$ unamended plots, the ruminant treatments were separated from the other two amendment treatments. This suggests that the ruminant amendment had more residual effects than alfalfa meal and monogastric amendments, which is consistent with well-known patterns of $\mathrm{N}$ release from ruminant and monogastric animal wastes (Mathers and Goss 1979).

The presence (1 or $2 \mathrm{yr}$ of forage) or absence of forages in rotations affected clustering of treatments other than those for which all treatment combinations were clustered by amendment type: in the 4th $\mathrm{yr}$ amended plots, $\mathrm{M} 1$ and $\mathrm{M} 2$ are clustered as are R1 and R2 and these are separated from the 0 -yr forage level treatments, which also clustered; in the 4th $\mathrm{yr}$ unamended plots, M1 and M2 are clustered as are S1 and $\mathrm{S} 2$ and these are separated from the 0 -yr forage level treatments, which also clustered (Fig. 1). This suggests that forages had relatively more influence on soil and plant properties for the soil amendments, but that alfalfa meal in the 4th yr amended plots and residues of ruminant compost in the 4th yr unamended plots had larger effects on soil and plant variables than did forage levels. The apparent lack of difference between the 1- and 2-yr forage levels may be attributable to several factors. (i) Red clover was substantially winter killed in the 2-yr forage treatments in the winter of yr 2; thus, the proportion of red clover biomass in yr 3 was actually lower in the 2-yr forage treatments $(42 \%)$ than in the $1-\mathrm{yr}$ forage treatments $(75 \%)$, which would lower potential benefits by nitrogen fixation accordingly. (ii) Treatments with forages had reduced dry tuber yields compared with the no-forage treatment $(5872,3648$, and $4638 \mathrm{~kg} \mathrm{ha}^{-1}$ for the $0-, 1-$, and 2 -yr forage levels, respectively; Liu 2006); forages preceded potatoes in both the 1- and 2-yr forage rotations, thus negative effects on the subsequent potatoes through allelopathic (Sturz and Christie 1996) or phytotoxic effects (Lynch 1983), or pest infestations (Ferro and Boiteau 1993; Powelson et al. 1993) are suspected. (iii) In yr 3, composts were applied based on $\mathrm{P}$ requirements for forages in the 1- and 2-yr forage treatments, but they were based on $\mathrm{N}$ requirements for the cereal crop (i.e., barley) in the 0 -yr forage rotation. Therefore, the 1- and 2-yr forage treatments received extra $\mathrm{N}$ compared with the 0 -yr forage treatment.

Overall, these results suggest that type of soil amendments had the largest effects on soil and plant variables, but forage frequencies were influential for the amendments and showed weaker effects on soil and plant 

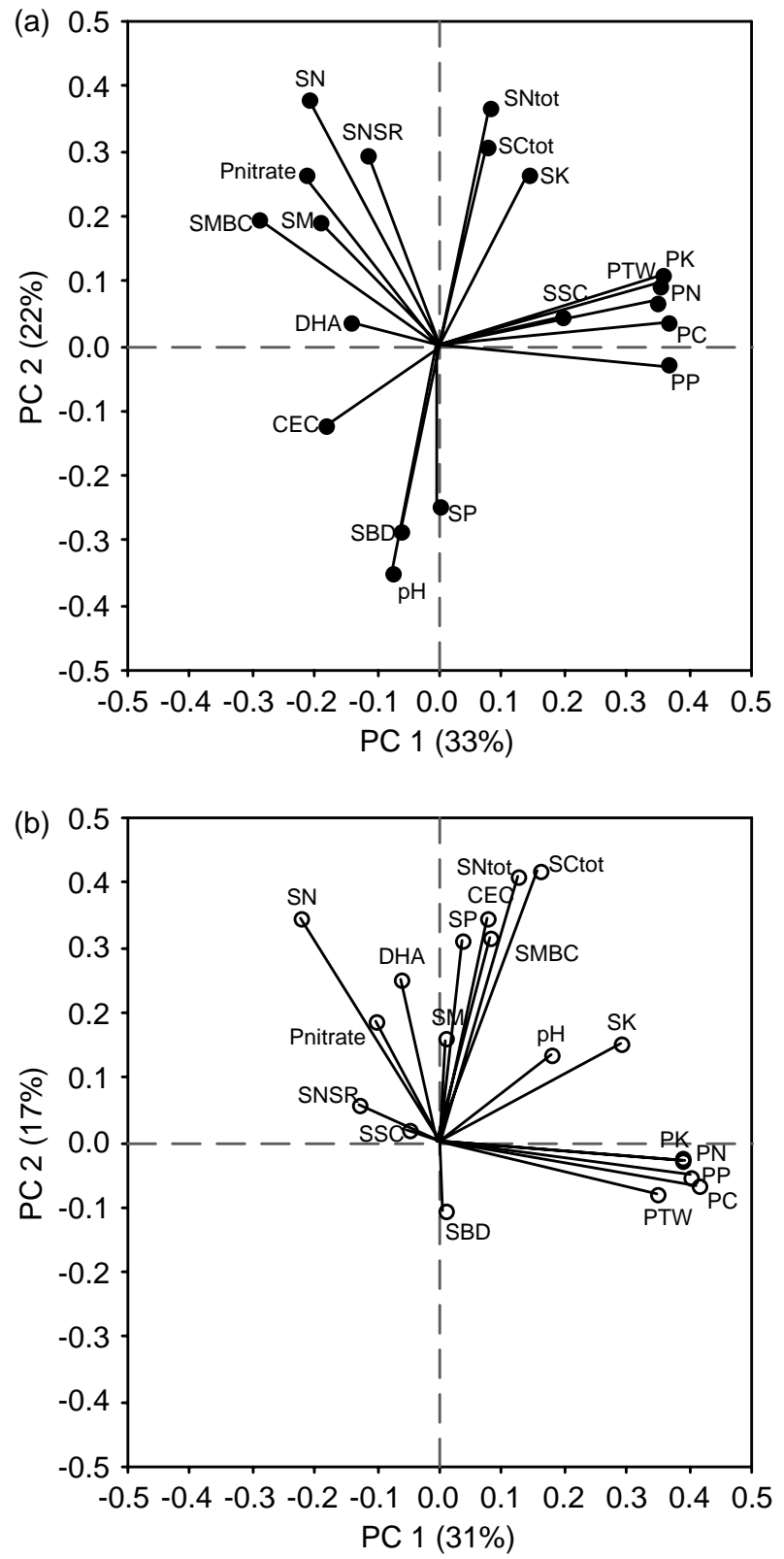

Fig. 2. Loading plots for the first two principal components (a) the 4th yr amended plots and (b) the 4th yr unamended plots. CEC, cation exchange capacity; DHA, dehydrogenase activity; PC, plant carbon biomass; PK, plant potassium uptake; PN, plant nitrogen uptake; Pnitrate, potato petiole nitrate content; PP, plant phosphorus uptake; PTW, dry potato tuber weight; $\mathrm{SBD}$, soil bulk density; $\mathrm{SC}_{\text {tot }}$, soil total carbon; $\mathrm{SK}$, soil extractable potassium; SM, soil moisture; SMBC, soil microbial biomass carbon; $\mathrm{SN}$, fall soil extractable nitrogen; $\mathrm{SN}_{\text {tot }}$, soil total nitrogen; SNSR, soil nitrogen supply rates; SP, soil extractable phosphorus; $\mathrm{SSC}$, soil $\mathrm{K}_{2} \mathrm{SO}_{4}$, soluble carbon. $\mathrm{pH}=6.65-18.5 \mathrm{~N}\left(R^{2}=0.299\right) \mathrm{pH}=6.49-14.0 \mathrm{~N}\left(R^{2}=0.096\right)$

variables. Porter et al. (2003) and Liebig et al. (2002) also reported that amendments can mask effects of crop rotations on yields and soil properties.

\section{Relationship of Soil and Plant Variables}

The length of the vectors in the loading plots is proportional to the relative importance of the individual variables in characterizing overall variation (James and McCulloch 1990). In the most important PC 1 direction, measures of plant nutrient uptake and potato total tuber dry weight are among the longest vectors (Fig. 2), suggesting that these variables would be the most valuable for characterizing the current cropping systems using a single variable. Similar conclusions could be drawn when comparing all soil and plant variables between the 4 th $\mathrm{yr}$ amended and unamended plots, since $67 \%$ of selected plant variables and only $31 \%$ of selected soil variables were significantly different (Table 2 ). This may be attributable to the plant variables reflecting processes of the entire system throughout a growing season, while most soil variables reflected either a particular point in time or a shorter period (e.g., extractable $\mathrm{N}$ ) or processes over much longer intervals (e.g., soil $\mathrm{C}_{\mathrm{tot}}$ ). Other studies have also identified that plant variables are important for evaluating management practices in a cropping system (Karlen et al. 2003). Plant biomass carbon was among the plant variables with the longest vector in the most important component PC 1, and thus might be used to represent plant variables for comparisons of different crops.

Soil $\mathrm{N}_{\text {tot }}$ is among the longest vectors in the PC 2 direction in both the 4th $\mathrm{yr}$ amended and unamended plots, and it might be used to represent soil variables when characterizing management effects on cropping systems similar to this study. De Clerck et al. (2003) found that the changes of the relative stable soil attributes such as soil total carbon and $\mathrm{N}$ reflect the essence of the farming practice effects. Organic $\mathrm{N}$ is the main form of $\mathrm{N}$ in organic cropping systems and becomes plant available $\mathrm{N}$ through $\mathrm{N}$ mineralization mediated by soil microorganisms. Soil biological variables are relatively sensitive to a slight change (Lupwayi et al. 2004), and can be used as early indicators of changing soil trends. Sensitive soil variables such as SMBC and DHA may, however, have large variations and poorly reflect soil changes. This current experiment was established on a fertile soil after a long-term sod was broken. The high soil $\mathrm{C}_{\text {tot }}$ levels (Table 2) could render soil biological indices (e.g., SMBC and DHA) less responsive (Cooper and Warman 1997). As well, the readily decomposable $\mathrm{C}$ and $\mathrm{N}$ might be depleted after one potato growing season. As a consequence, SMBC and DHA were less important in this study for characterizing the soil differences among cropping systems.

The display patterns in loading plots illustrate the degree of covariation or correlation among the variables (Table 3 and Fig. 2). In the most important principal component PC 1 direction, plant nutrient uptake and potato total tuber dry weight were displayed closely together (Fig. 2), but they were not highly correlated (positively or negatively) overall with the soil variables collectively or individually. This may reflect the overall 
Table 3. Correlations among selected soil and plant variables in the 4th year amended and unamended organic potato plots

\begin{tabular}{|c|c|c|c|c|c|c|c|c|c|c|c|c|c|c|c|c|c|c|c|}
\hline & SBD & SM & PH & ECE & $\mathrm{SC}_{\text {tot }}$ & $\mathrm{SN}_{\text {tot }}$ & SN & SNSR & SP & SK & SC & SMBC & DHA & Pnitrate & PC & PN & PP & PK & PTW \\
\hline $\mathrm{SBD}^{\mathrm{y}}$ & & -06667 & 0.0914 & 0.0404 & -0.1083 & -0.0994 & -0.3442 & -0.0721 & 0.1192 & -0.1520 & -0.2394 & 0.1831 & 0.2303 & -0.3001 & -0.0444 & -0.1063 & 0.0037 & -0.0132 & 0.0699 \\
\hline SM & -0.2202 & & 1297 & 0.0965 & 0.1846 & 0.1989 & 0.1931 & -0.0041 & -0.0959 & 0.0731 & 0.2772 & 0.0032 & -0.1422 & 0.2926 & 0.0459 & 0.0218 & -0.0242 & & 0.0657 \\
\hline $\mathrm{pH}$ & 0.2577 & -0.0256 & & 0.5024 & 0.2634 & 0.0250 & -0.3093 & -0.2768 & 0.5271 & 0.2178 & -0.0063 & 0.2854 & 0.0060 & -0.5367 & 0.2942 & 0.2579 & 0.3532 & 0.2344 & 0.1876 \\
\hline ECE & 0.0013 & 0.0303 & 0.4122 & & 0.2614 & 0.2785 & 0.1542 & -0.1094 & 0.5819 & 0.3195 & -0.2680 & 0.4528 & 0.1401 & 0.0018 & -0.0118 & 0.0152 & 0.0752 & 0.0929 & 0.0060 \\
\hline $\mathrm{SC}_{\text {tot }}$ & -0.3913 & 0.0106 & -0.2892 & 0.0579 & & 0.8474 & 0.1827 & 0.0930 & 0.4116 & 0.3683 & 0.1417 & 0.3266 & 0.1757 & 0.2466 & 0.3008 & 0.4091 & 0.29 & 0.3 & 0.0613 \\
\hline $\mathrm{SN}_{\text {tot }}$ & -0.4405 & 0.0923 & -0.4748 & 0.0358 & 0.8749 & & 0.3047 & 0.2512 & 0.1855 & 0.4500 & 0.1708 & 0.3017 & 0.1625 & 0.3263 & 0.2582 & 0.3077 & 0.1936 & 0.2368 & 0.1215 \\
\hline SN & -0.3720 & 0.4870 & -0.5468 & 0.0585 & 0.3627 & 0.5205 & & 0.2790 & 0.0986 & -0.0376 & 0.2081 & 0.1417 & 0.3428 & 0.4319 & -0.5226 & -0.4590 & -0.5345 & -0.4117 & -0.6538 \\
\hline SNSR & -0.1817 & 0.2507 & -0.3770 & -0.2948 & 0.1835 & 0.2185 & 0.5528 & & -0.0991 & -0.0141 & 0.1594 & -0.3196 & -0.1386 & 0.1027 & -0.2512 & -0.184 & -0.3576 & -0.2015 & -0.2941 \\
\hline SP & 0.2741 & -0.3809 & 0.4095 & 0.5060 & 0.0999 & 0.0552 & -0.2634 & -0.5452 & & 0.1211 & -0.0488 & 0.1915 & 0.1736 & -0.17 & -0.0 & -0.0042 & & & -0.2827 \\
\hline SK & -0.2907 & 0.0025 & -0.3674 & -0.1106 & 0.5487 & 0.6380 & 0.1857 & 0.0770 & -0.0196 & & 0.1671 & 0.0568 & -0.1547 & 0.0548 & 0.6288 & 0.5914 & 0.6138 & 0.7439 & 0.5149 \\
\hline $\mathrm{SC}$ & -0.1183 & -0.2568 & -0.0873 & -0.4548 & 3056 & 27 & -0.1436 & -0.0224 & -0.1358 & 0.2674 & & -0.5164 & -0.1233 & & -0.0794 & -0.1 & -0 . & -0 . & -0.0607 \\
\hline SMBC & 0.02 & 0.5783 & -0.23 & 0.3525 & 358 & 0 & 0.6877 & & -0.1182 & -0.0967 & -0.6224 & & 0.6576 & 0.0345 & 0.1118 & 0.09 & & & 0.0024 \\
\hline DHA & 0006 & 3237 & & 024 & 141 & 0 & 0.2369 & -0.2217 & 0.0296 & -0.1575 & -0.2142 & 0.4841 & & -0.1223 & -0.1490 & -0.2208 & -0.12 & -0.13 & -0.2640 \\
\hline Pnitrate & & & -0.375 & -0.0027 & -0.0034 & & & & -0.47 & & -0.4367 & 0.5911 & 0.0999 & & -0.2197 & -0.1493 & & -0 . & -0.1709 \\
\hline PC & -0.1842 & -0.3365 & -0.3033 & -0.4005 & 0.1294 & 1735 & -0.4093 & -0.2641 & -0.0736 & 0.2293 & 0.2228 & -0.5101 & -0.2271 & -0.3996 & & 0.9360 & 0.9645 & 0.92 & 0.8454 \\
\hline & & -0.2500 & -0.2856 & -0.4099 & & & -0.3035 & -0.1246 & -0.18 & & & -0.4731 & -0.2150 & -0.2796 & 0.93 & & 0.9423 & & 0.7555 \\
\hline PP & -0.1310 & -0.3914 & -0.1468 & -0.3138 & 0.0666 & 0.1059 & -0.5262 & -0.3186 & 0.0071 & 0.1872 & 0.1819 & -0.5763 & -0.1876 & -0.4476 & 0.9551 & 0.9261 & & 0.9341 & 0.7972 \\
\hline PK & -0.2420 & -0.2855 & -0.3775 & -0.3599 & 0.2408 & 0.3261 & -0.3246 & -0.2684 & -0.1074 & & 0.2854 & -0.4493 & -0.1754 & -0.3 & 0.8936 & 0.8851 & 0.8728 & & 0.7857 \\
\hline PTW & -0.2401 & -0.3092 & -0.2668 & -0.4768 & 0.2438 & 0.2558 & -0.4012 & -0.1621 & -0.1135 & 0.2794 & 0.3749 & -0.5093 & -0.3196 & -0.3484 & 0.8073 & 0.7632 & 0.7802 & 0.7706 & \\
\hline
\end{tabular}

${ }^{\mathrm{z}}$ The correlations in the lower-left and top-right triangles divided by the diagonal line are for the 4th yr amended and unameded plots, respectively.

y Abbreviations: CEC, cation exchange capacity; DHA, dehydrogenase activity; PC, plant carbon biomass; PK, plant potassium uptake; PN, plant nitrogen uptake; Pnitrate, potato petiole nitrate content; PP, plant phosphorus uptake; PTW, dry potato tuber weight; SBD, soil bulk density; $\mathrm{SC}_{\mathrm{t}}$, soil total carbon; SK, soil extractable potassium; SM, soil moisture; SMBC, soil microbial biomass carbon; $\mathrm{SN}$, fall soil extractable nitrogen; $\mathrm{SN}_{\text {tot }}$, soil total nitrogen; $\mathrm{SNSR}$, soil nitrogen supply rates; $\mathrm{SP}$, soil extractable phosphorus; $\mathrm{SSC}$, soil $\mathrm{K}_{2} \mathrm{SO}_{4}$, soluble carbon.

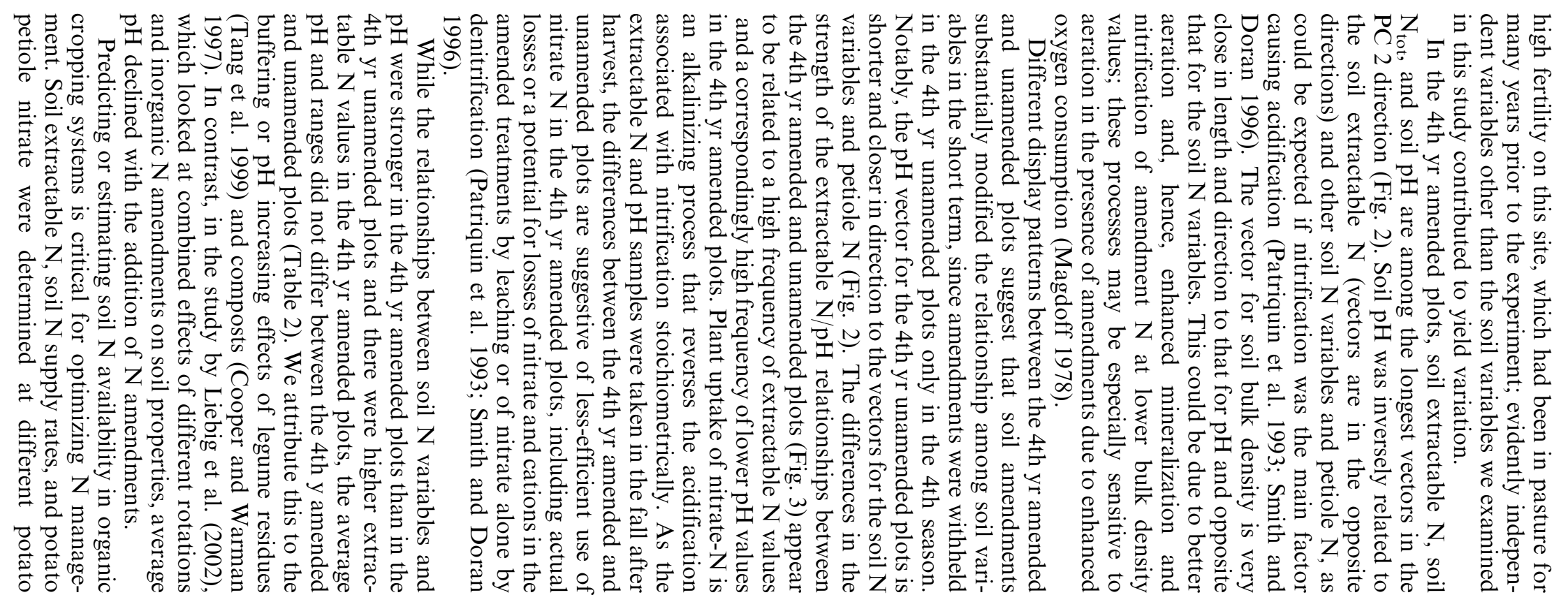




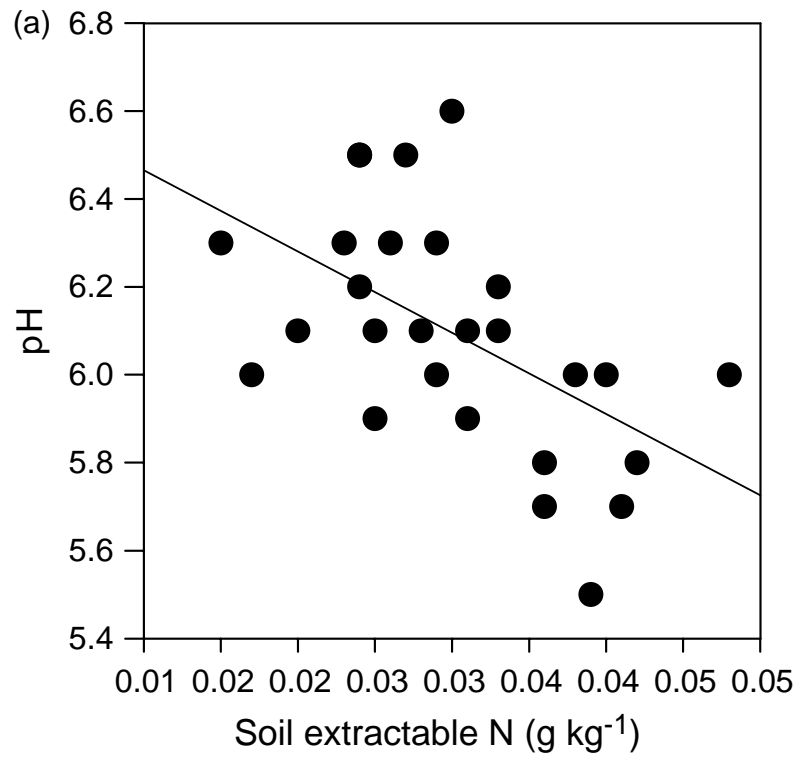

(b)

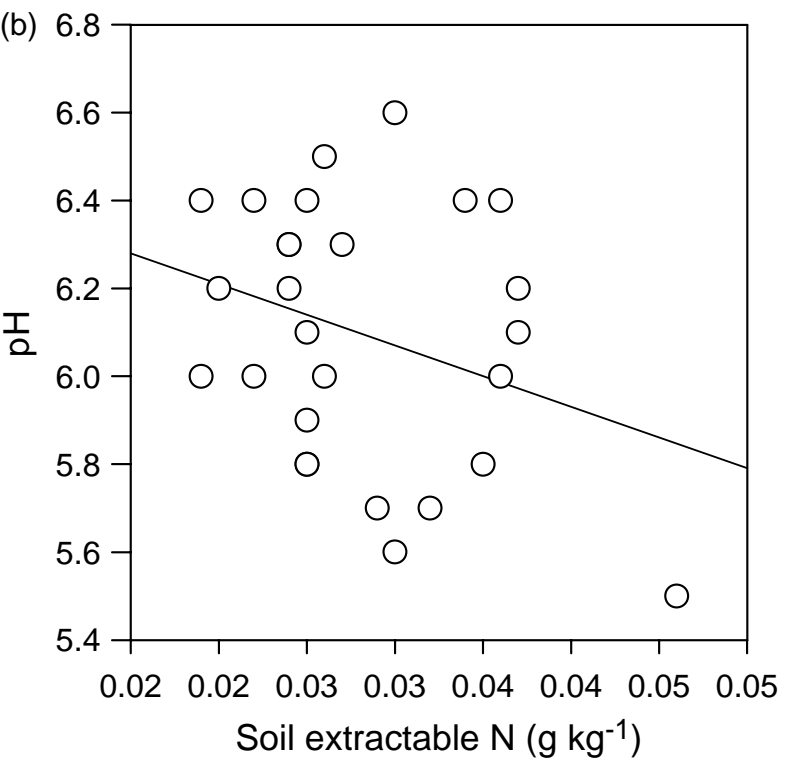

Fig. 3. Relationships between soil $\mathrm{pH}$ and extractable $\mathrm{N}$ (a) the 4th yr amended plots and (b) the 4th yr unamended plots at the end of potato growing season.

growing stages, but they were closely displayed in the loading plots (Fig. 2), since all of them reflect soil N availability. Such relationships have been reported in other studies. Sanderson et al. (1999) reported that potato petiole nitrate as a plant-based diagnostic method was a good predictor of soil available $\mathrm{N}$ levels. Soil $\mathrm{N}$ supply rates, determined by ion exchange membranes, have also been found to be effective indicators of plant available N (Qian and Schoenau 1995). These three soil and plant variables reflect soil $\mathrm{N}$ availability; however, soil variables are preferred under high soil fertility circumstances, while plant variables are preferred under low soil fertility circumstances (Mengel and Kirkby 1987). In this study, soil extractable N displayed more closely with potato petiole nitrate in the 4th yr unamended plots, but closely with soil $\mathrm{N}$ supply rates in the 4th yr amended plots.

\section{CONCLUSIONS}

The current experiment simulated the realistic nutrient management by organic farmers of stockless (crops only) and mixed, livestock systems. Similar to organic farmers' practices, both forages and soil amendments were used as $\mathrm{N}$ resources to equalize soil available $\mathrm{N}$ levels, but they were interdependent and integrated in management practices. Under such management, PCA provides an effective way to extract key information from a large data set, especially when the power of significance tests is limited because of a low number of replicates and/or high site heterogeneity. Patterns revealed by PCA were explicable by known processes and/ or have been observed in other studies. Principal component analysis suggested that soil and crop variables characterizing nine cropping systems were more affected by the type of soil amendments than by crop sequence, at the end of the first cycle of a four-course rotation, but forage effects were also evident. Plant variables appear to be better indicators than soil variables for monitoring these cropping systems under the conditions of our experiment. Withholding soil amendments in the 4th $\mathrm{yr}$ affected the relationships between variables, notably, inverse relationships of soil $\mathrm{N}$ variables to $\mathrm{pH}$ were stronger in the plots receiving amendments than in plots without amendments; this is suggestive of some inefficiencies in use of amendment $\mathrm{N}$, even though average $\mathrm{pH}$ was not lowered in the 4th $\mathrm{yr}$ amended plots compared with the unamended plots.

\section{ACKNOWLEDGEMENTS}

The authors gratefully acknowledge funding provided by the Natural Sciences and Engineering Research Council (NSERC). Technical personnel and summer students at the Organic Agriculture Centre of Canada provided excellent assistance.

Andrews, S. S. and Carroll, C. R. 2001. Designing a soil quality assessment tool for sustainable agroecosystem management. Ecol. Appl. 11: 1573-1585.

Angers, D. A., Edwards, L. M. and Sanderson, J. B. 1999. Soil organic matter quality and aggregate stability under eight potato cropping sequences in a fine sandy loam of Prince Edward Island. Can. J. Soil Sci. 79: 411-417.

Bakken, A. K., Breland, T. A., Haraldsen, T. K., Aamlid, T. S. and Sveistrup, T. E. 2006. Soil fertility in three cropping systems after conversion from conventional to organic farming. Acta Agric. Scand. Sect. B Plant Soil Sci. 56: 81-90.

Carter, M. R., Kunelius, H. T., Sanderson, J. B., Kimpinski, J., Platt, H. W. and Bolinder, M. A. 2003. Productivity parameters 
and soil health dynamics under long-term 2-year potato rotations in Atlantic Canada. Soil Tillage Res. 72: 153-168.

Clarke, K. R. and Warwick, R. M. 2001. Plymouth routines in multivariate ecological research (PRIMER) user manual. 2nd ed. Plymouth Marine Lab., Plymouth, UK.

Cooper, J. M. and Warman. P. R. 1997. Effects of three fertility amendments on soil dehydrogenase activity (DHA), organic C and pH. Can. J. Soil Sci. 77: 281-283.

De Clerck, F., Singer, M. J. and Lindert, P. 2003. A 60-year history of California soil quality using paired samples. Geoderma 114: 215-230.

Ferro, D. N. and Boiteau, G. 1993. Management of insect pests. Pages 103-115 in R. C. Rowe, ed. Potato health management. The American Phytopathological Society (APS) Press, St. Paul, MN.

Gil-Sotres, F., Trasar-Cepeda, C., Leirós, M. C. and Seoane, S. 2005. Different approaches to evaluating soil quality using biochemical properties. Soil Biol. Biochem. 37: 877-887.

James, F. C. and McCulloch, C. E. 1990. Multivariate analysis in ecology and systematics: panacea or Pandora's box? Annu. Rev. Ecol. Syst. 21: 129-166.

Karlen, D. L., Ditzler, C. A. and Andrews, S. S. 2003. Soil quality: why and how? Geoderma 114: 145-156.

Liebig, M. A., Varvel, G. E., Doran, J. W. and Wienhold, B. J. 2002. Crop sequence and nitrogen fertilization effects on soil properties in the Western Corn Belt. Soil Sci. Soc. Am. J. 66: 596-601.

Liu, K. 2006. Soil and plant responses in the first cycle of fouryear organic potato rotations. Ph.D. thesis, Dalhousie University, Halifax, NS. 150 pp.

Lynch, J. M. 1983. Soil biotechnology: microbiological factors in crop productivity. Blackwell Scientific, Oxford, UK. 191 pp. Lupwayi, N. Z., Clayton, G. W., O'Donovan, J. T., Harker, K. N., Turkington, T. K. and Rice, W. A. 2004. Soil microbiological properties during decomposition of crop residues under conventional and zero tillage. Can. J. Soil Sci. 84: 411-419.

Magdoff, F. R. 1978. Influence of manure application rates and continuous corn on soil nitrogen. Agron. J. 70: 629-632.

Mathers, A. C. and Goss, D. W. 1979. Estimating animal waste applications to supply crop nitrogen requirements. Soil Sci. Soc. Am. J. 43: 364-366.

Marinari, S., Mancinelli, R., Campiglia, E. and Grego, S. 2006. Chemical and biological indicators of soil quality in organic and conventional farming systems in Central Italy. Ecol. Ind. 6: 701-711.

Maynard, D. G. and Kalra, Y. P. 1993. Nitrate and exchangeable ammonium N. Pages 25-38 in M. R. Carter, ed. Soil sampling and methods of analysis. Lewis publishers, Boca Raton, FL.

Mehlich, A. 1984. Mehlich 3 soil test extractant: A modification of Mehlich 2 extractant. Commun. Soil Sci. Plant Anal. 15: $1409-1416$.

Mengel, K. and Kirkby, E. A. 1987. Principles of plant nutrition. 4th ed. International Potash Institute, Bern, Switzerland. $687 \mathrm{pp}$.

Minitab Inc. 2004. MINITAB ${ }^{\circledR}$ release 14.13 statistical software. Minitab Inc., PA.

Mkhabela, M. S. and Warman, P. R. 2005. The influence of municipal solid waste compost on yield, soil phosphorus availability and uptake by two vegetable crops grown in a
Pugwash sandy loam soil in Nova Scotia. Agric. Ecosyst. Environ. 106: 57-67.

Patriquin, D. G., Blaikie, H., Patriquin M. and Yang C. 1993. On farm measurements of $\mathrm{pH}$, electrical conductivity and nitrate for monitoring coupling and decoupling of nutrient cycles. Biol. Agric. Hortic. 9: 231-272.

Porter, P. M., Huggins, D. R., Perillo, C. A., Quiring, S. R. and Crookston, R. K. 2003. Organic and other management strategies with two- and four-year crop rotations in Minnesota. Agron. J. 95: 233-244.

Powelson, M. L., Johnson, K. B. and Rowe, R. C. 1993. Management of diseased caused by soil borne pathogens. Pages 149-158 in R. C. Rowe, ed. Potato health management. The American Phytopathological Society (APS) Press, St. Paul, MN

Qian, P. and Schoenau, J. J. 1995. Assessing nitrogen mineralization from soil organic matter using anion exchange membranes. Fert. Res. 40: 143-148.

Robertson, G. P., Klingensmith, K. M., Klug, M. J., Paul, E. A., Crum, J. R. and Ellis, B. G. 1997. Soil resources, microbial activity, and primary production across an agricultural ecosystem. Ecol. Appl. 7: 158-170.

Rodd, A. V., Warman, P. R., Hicklenton, P. and Webb, K. 2002. Comparison of $\mathrm{N}$ fertilizer, source-separated municipal solid waste compost and semi-solid beef manure on the nutrient concentration in boot-stage barley and wheat tissue. Can. J. Soil Sci. 82: 33-43.

SAS Institute, Inc. 1999. SAS 8.0 for Windows and SAS/STAT software and user's guide. SAS Institute, Inc., Cary, NC.

Sanderson, J. B., Macleod, J. A. and Kimpinski, J. 1999. Glyphosate application and timing of tillage of red clover affects potato response to $\mathrm{N}$, soil $\mathrm{N}$ profile, and soil nematodes. Can. J. Soil Sci. 79: 65-72.

Schulte, E. E., Peters, J. B. and Hodgson, P. R. 1987. Wisconsin procedures for soil testing, plant analysis and feed $\&$ forage analysis. No. 6 Soil Fertility Series. University of Wisconsin, Marshfield, WI.

Sena, M. M., Frighetto, R. T. S., Valarini, P. J., Tokeshi, H. and Poppi, R. J. 2002. Discrimination of management effects on soil parameters by using principal component analysis: a multivariate analysis case study. Soil Tillage Res. 67: 171-181. Smith, J. L. and Doran, J. W. 1996. Measurement and use of $\mathrm{pH}$ and electrical conductivity for soil quality analysis. Pages 169-185 in J. W. Doran and A. J. Jones, eds. Methods for assessing soil quality. SSSA Spec. Publ. 49. SSSA, Madison, WI.

Stark, J. C. and Porter, G. A. 2005. Potato nutrient management in sustainable cropping system. Am. J. Potato Res. 82: 329-338.

Sturz, A. Z. and Christie, B. R. 1996. Endophytic bacteria of red clover as agents of allelopathic clover-maize syndromes. Soil Biol. Biochem. 28: 583-588.

Tang, C., Sparling, G. P., Mclay, C. D. A., Tang, C. and Ralphael, C. 1999. Effect of short-term legume residue decomposition on soil acidity. Aust. J. Soil Res. 37: 561-574. von Mersi, W. and Schinner, F. 1991. An improved and accurate method for determining the dehydrogenase activity of soils with iodonitrotetrazolium chloride. Biol. Fertil. Soils 11: 216-220.

Voroney, R. P., Winter, J. P. and Beyaert, R. P. 1993. Soil microbial biomass C and N. Pages 277-286 in M. R. Carter, 
ed. Soil sampling and methods of analysis. Lewis publishers, Boca Raton, FL.

Warman, P. R. and Cooper, J. M. 2000. Fertilization of a mixed forage crop with fresh and composted chicken manure and NPK fertilizer: effects on dry matter yield, legume content, and soil and tissue N, P, K. Can. J. Soil Sci. 80: 337-344.
Zheljazkov, V. D. and Warman, P. R. 2002. Comparison of three digestion methods for the recovery of 17 plant essential nutrients and trace elements from six composts. Compost Sci. Util. 10: 197-203. 